\title{
BRITISH CLUBS IN INDIA AND REINFORCEMENT OF BRITISH NATIONAL/IMPERIAL IDENTITY: TOM STOPPARD'S INDIAN INK
}

\author{
Hindistan'daki İngiliz Kulüpleri ve Millî/Emperyalist Kimliğin Pekiştirilmesi: \\ Tom Stoppard'in Indian Ink Adlı Oyunu
}

İmren YELMiş*

\begin{abstract}
Throughout the British Raj, British colonisers built many clubs in India. These clubs functioned as socialising areas for the British where they met, danced, listened to music, played polo/cricket, read newspapers and magazines, and held conversations. They were also race-selective; they accepted particularly the British (and some of them accepted Europeans, as well) as members or guests, and excluded indigenous Indians. Moreover, they had been instruments for the British to enforce their national and imperial identities in India. In this sense, the British club in India was a microcosm of Britain, the representation of the British Empire's ideologies and a symbol of racism. British colonisation in India, power relations and hegemonic struggles between the coloniser and the colonised in this colony had been significant issues that have attracted the attentions of many literary and historical figures, and have been topics for many literary works. Within the light of these points, and in relation to Tom Stoppard's Indian Ink, this article aims to discuss the function of the British club in India as an imperial institution that reflects the Eurocentric worldview, East-West dichotomy, and British national and imperial ideologies during the British Raj.
\end{abstract}

Keywords: British clubs in India, the British Raj, British national and imperial identity, Tom Stoppard, Indian Ink.

\section{Öz}

Britanya Hindistan'ında, İngiliz emperyalistler, sömürgecilik dönemindeki İngiliz egemenliği boyunca pek çok kulüp kurmuşlardır. Bu binalar, İngilizlerin buluştuğu, dans ettiği, müzik dinlediği, polo/kriket oynadığı, gazete/dergi okuduğu ve sohbet ettiği alanlardı. Bu kulüpler, ayrıca, ırk ayrımı yapıyorlardı ve sadece ingiliz (bazıları da Avrupalı) üye ve misafirleri kabul edip yerli Hindistanlıları dışlıyorlardı. Bunun yanı

\footnotetext{
* Asst. Prof. Dr., Hacettepe University, Faculty of Letters, Department of English Language and Literature, Ankara/Turkey. E-mail: imren.yelmis@hacettepe.edu.tr. ORCID: 0000-0003-13162191. 
sıra, bu mekânlar, İngilizlerin kendi millî ve emperyalist kimliğini güçlendirmek amacıyla kullandıkları bir araç özelliği göstermekteydi. Bu bağlamda, ingiliz kulübü, Britanya'nın küçük bir yansıması, Britanya imparatorluğu'nun ideolojilerinin temsili ve ırkçılık sembolüydü. Hindistan'daki İngiliz sömürgeciliği, sömürgeci ile sömürgeci arasındaki güç ilişkileri ve bu sömürgedeki hegemonik mücadeleler, birçok edebi ve tarihi şahsiyetin dikkatini çeken önemli konular olmuş ve birçok edebi esere konu olmuştur. Bu makale, tüm bu noktalar ışığında ve Tom Stopard'ın Indian Ink adlı oyunu çerçevesinde, Hindistan'daki İngiliz kulüplerinin, ingiliz hâkimiyeti boyunca sahip olduğu Avrupa-merkezcilik görüşünü, Doğu-Batı ikilemini ve ingiliz millî ve emperyalist kimliğini yansıtan bir işlevi olduğunu tartışmayı amaçlamaktadır.

Anahtar Sözcükler: Hindistan'daki ingiliz kulüpleri, Hindistan'da Ingiliz hâkimiyeti, Ingiliz millî ve emperyalist kimliği, Tom Stoppard, Indian Ink.

\section{Introduction}

British colonisation in India, power relations and hegemonic struggles between the coloniser and the colonised in this colony had been significant issues that have attracted the attentions of many literary and historical figures, and have been topics for many literary works. One of the most outstanding literary works reflecting such topics is, without doubt, Indian Ink (1995) by Tom Stoppard (Tomáš Straussler), who was born in the Czech Republic, and who lived in Singapore, India and England. About the cultural dimension of Stoppard's experience of living in multiple nations, Richard Rankin Russell puts forth that Stoppard's "global origins have inspired a fascination with national identities, particularly the ones in which these identities are interrelated" (2004: 1). In Indian Ink, as well, one can observe the traces and discussions of "interrelated" national identities between the Indians and the British within two different decades in line with British imperial ideologies, and colonial and postcolonial discussions: One represents the cultural and national identity issues of the Indians and the British in the 1930s (the colonial period) in India, by means of the discussions between Flora Crewe, an English poet who has come to Jummapur due to health problems and Nirad Das, an educated Indian artist who is a mimic man, and the conversations between Durance, an English colonial agent in India and Flora. Stoppard states that he wrote Indian Ink "thinking that there would be something to explore in the huge subject of colonialism, and the British Empire, and all that" (qtd. in Bhatia, 2009: 223). He, in the part that takes place in the 1930s, rewrites the colonial past of India. The other decade, which covers the 1980s in England, on the other hand, is reflective of the postcolonial period. This part is reflected by means of the discussions be- 
tween Anish Das, an artist like his father, Nirad Das, and Elenaor Swan, Flora's younger sister. Since the focus of this paper is on the colonial British clubs in India and these clubs are mainly discussed throughout the colonial period in the play, the conversations particularly between Flora and Durance and the stage directions reflecting the 1930s will be taken into consideration.

Throughout the British colonisation period in India, British colonisers in this colony maintained close links with their own culture and national identity. Besides, the struggle of many imperialist-minded British people to preserve and enhance their hegemonic power, their national and imperial identity resulted in racism in the social, political and cultural life. These circumstances and the separation from the indigenous people with some strict lines by means of some buildings hide in themselves many historical truths as regards British colonialism in India such as race issues, East-West dichotomy, and national identity. On the pretext that the colonised were "primitive" (Prakash, 1994: 3), "indolent, malingerers, shirkers, good-fornothings, layabouts, degenerate versions of the pastoral idler" (Boehmer, 1995: 39), colonisers searched for new spheres in which they could be away from the meeting places of the colonised like the bazaars. As a result, they began to design and construct new buildings such as bungalows, schools and clubs whose doors were open to particularly the British and many Europeans. These places turned into symbolic areas which represented British cultural, nationalistic and imperialistic ideologies and identities, and which had been used as instruments to generate artificial differences between the dominator and the colonial subject, between the European and nonEuropean, between the "self" and the "other" and between the East and the West. In this regard, the central point of this paper will be based on the club, which is emblematic of British India, and in which "the contexts of empire and colony are spatially located" (Bhatia, 2009: 223). Within the light of these discussions, this paper aims to analyse the British clubs in India and their representation in Stoppard's Indian Ink as spaces for the British colonisers which endorse British racial, imperial and national ideologies, and which, as a consequence, shape the political culture in India.

\section{Emergence of Imperial Social Clubs in Britain}

Before analysing Indian Ink in relation to the representation of the clubs as national and imperial spheres, it might prove useful to give brief information about the historical development and the cultural and political significance of the clubs for the British. The club, before its emergence in the 
British colonies, had already been a place for entertainment, for the socialisation of the British, for the discussions of literature and politics in Britain, particularly in England at the end of the eighteenth century and the beginning of the nineteenth century. It seems that in the emergence of many clubs in England, coffee houses were influential (Sinha, 2001: 493). They were like more developed versions of the coffee houses in Britain.

In addition to such clubs as Traveller's, Turf, Carlton, Marlborough, Brook's, Bachelors, St. James's, Whites, Arthur's, Pratts, and the New Club (Sinha, 2001: 494), which were places particularly for gathering-fordiscussions purposes, gradually some clubs related to the imperial discourses of the country had been founded in Britain. With the rise of imperialism and the increase in the number of the colonies in the overseas, and, particularly after the colonisation of India, the ones who had tenures in the overseas found it necessary to come together when they were in Britain, as they were in need of like-minded people with whom they shared similar cultural and political codes. It was a need particularly for many who had been indulged in colonial duties in the colonies for many years and turned back to Britain, and who had "culture shock." As a result, many clubs began to accept in the 1820s the ones who had once worked or travelled in colonies: The Alfred Club (that had many imperialist members), the Travellers (that accepted particularly long-distance male travellers - more than 500 miles from London), the United Service (open to the ones in Her Majesty's Forces from 1825 on), the Army and Navy Club (established in 1838) (URL3 ). In addition to these clubs, there were some clubs only for the ones who had connections with the "East". In order to formulate ways of connections between the "hybrid" Anglo-Indians and England, and stop this hybridity's being a problem, ways of solving the problems such as communicational instruments had been used: In Asiatic Journal whose sponsor was the East India Company, for example, such a notice was seen in April 1824: "The British Empire in the East is now so expensive, and the persons connected with it so numerous, that the establishment of an institution where they met on a footing of social intercourse, seems particularly desirable" (URL-3). Here, the need for a club that would connect the ones with such a demand is emphasised. As a result, in 1824, the London Oriental Club was founded, and, the East India United Services Club at 14 St. James's Street was established in 1848 "to meet the wants of the various services which administer the Indian Government" (Timbs, 1867: 248). The East India Club served the ones from different professions who had been indulged in colonial services 
in British India, as it "consist[ed] of gentlemen who [were] or [had] been commissioned officers in Her Majesty's or the East Indian army or navy; members of the Indian civil, ecclesiastical, or medical services; judges of a high or civil court; members of a legislative council; or law officers of government in India" (Dickens, 1882: 97). Similarly, the London Oriental Club was "an iconic Central London focal point for those who [had] lived, worked or travelled in the East" (URL-4). These two clubs were different from the previously referred ones in that these two had been founded to provide the "hybrid identities of the returning men of the Empire" (URL-3) with what they needed: conversations only with the ones with whom they shared similar cultural and political experiences, and who could understand the psychology of having a "hybrid identity" as Anglo-Indians. Both of these clubs were of vital importance as regards the service they provided for the ones who were in close connection with the "East". Their members from all social strata who had served the Empire in her colonies are reflective of the close connections of these clubs with the imperial ideologies of Britain.

Development of British Clubs in India in Parallel with National and Imperial Ideologies

In fact, Britain's colonial expansion framed the socio-cultural atmosphere not only in Britain but also in the colonial domains like India where the British were in need of familiar atmospheres in the colonies which were culturally and geographically different from Britain. The outcome of such a need was the establishment of many clubs in her colonies where they performed cultural and political discussions. In British India where colonial duties were tedious and laborious, British colonisers saw the club as a place to de-stress and to relax, and to enjoy a brief break from the complexities of the discourse of the British Raj. Benjamin B. Cohen states that "the next wave of club openings took place in the British hill stations. These cooler seasonal destinations were respites from urban colonial life, and many hill stations soon had their own clubs" (2009: 171-172). Those clubs, among many other services, also functioned as socialising areas for the British where they met, danced, listened to music, played polo and cricket, read newspapers and magazines, held conversations about their daily lives and colonial duties, and organised cultural and entertaining activities. Similarly, in Tom Stoppard's Indian Ink, some activities of the Jummapur Cricket Club are observed to be as follows: "usually dancing on Saturdays, only a gramophone but lots of fun" (Stoppard, 1999: 399); playing cricket (Stoppard, 1999: 433) and polo (Stoppard, 1999: 431); reading poems particularly the 
ones written by Rudyard Kipling (Stoppard, 1999: 433), and discussing political, imperial and cultural issues such as the celebration of the birthday of Queen Victoria (Stoppard, 1999: 432), who represents British imperial ideologies with her political and imperialistic policies.

Besides, the decorations, furniture and the architectural planning in British clubs in India were not much different from those observed in Britain. Lilian Ricketts, the wife of an Indian colonel drew attention to the "exaggerated Englishness of the decorations and pastimes" of the distinctive British clubs in India (James, 1997: 311). As a result, one could feel as if s/he were in homeland rather than in a foreign land. This familiarity is expressed in Indian Ink as follows in a letter written by Flora to her sister, Elenaor, which is about her first impressions about the Jummapur Cricket Club during her visit to India: "I thought the club would be like a commercial hotel in the hotter part of Reigate, but not at all - it was huge and white and pillared, just like the house of your first memory, perhaps - poor mama's nearlyhouse, which was ours for six months and then no more"' (Stoppard, 1999: 437). The Jummapur Cricket Club, with the "Long-sleever [which is] [g]ood for putting the feet up" (Stoppard, 1999: 439), its verandah (Stoppard, 1999: 433) and its architectural arrangements, enables Flora to feel at home and among the people with whom she shares similar cultural and national codes. As exemplified in the Jummapur Cricket Club as well, the colonial British club, with its national and cultural celebrations, national sport and entertainment activities, represents the microcosm of Britain.

At this point, it would be relevant to briefly talk about how these national and cultural activities and celebrations served the collective national/ imperial identity and consciousness throughout the British Raj. One of the most outstanding examples in Indian Ink is the traditional celebration of the birthday of Queen Victoria, who is the national and symbolic figure of British imperialism, and who is associated with the expansion of the British Empire into one of the largest in history. In the play, Flora, as a guest, is informed in the club about the national celebration of the Queen's birthday as follows:

Englishwoman: Will you be here for the Queen's Ball, Flora?

Flora: The...?

Englishwoman: It comes off next month, Queen Victoria's birthday! (Stoppard, 1999: 432). 
By means of symbols such as ceremonies, in fact, "members are reminded of their common heritage and cultural kinship and feel strengthened and exalted by their sense of common identity and belonging" (Smith, 1991: 1617). These facts make the club more than a socialising area; they are also the places where nation-building process and "nationalistic potential, with sentimental reminders of England and empire, and with images of white solidarity" (Laurie Kaplan, qtd. in Crane, 2011: 21) are made possible. The preservation of these traditional celebrations, the "ceremonies of remembrance for the national dead" (Smith, 1991: 77) enhanced and strengthened the cultural, imperial, racial, national, and political connections of the same-race members of the club. Moreover, such cultural activities are, in Homi K. Bhabha's words, "collective experiences of nationness, community interest, or cultural value" (2002: 2). They constitute social, political and cultural solidarity and the feeling of shared identity. The club enhanced cultural and national codes, and, in a way, re-structured Britain in India. British imperial history proves that, throughout British imperialism that began to emerge progressively in the $16^{\text {th }}$ century and that gradually declined with World War II, the British had never deviated from their national and imperial course in their colonial routes. In other words, while they were following their colonial routes, they always preserved their roots/ cultural and national identities/ all that is British/English; they never ceased to look into their roots/ traditions. In this regard, one might conclude that creation of this national feeling, identity and atmosphere is constructed, and the clubs enabled the British in India to come together under the roof of a building. These characteristics make the club important as a concrete place that has symbolic significance in socio-cultural and national terms, which is put into words by Mrinalini Sinha as follows: "For more than a century no institution has been more peculiarly British than the social club" (2001: 490). The architectural arrangement in English style and the national pastime activities such as celebrations trigger one to reconsider the club in India as a construction that made the reinforcement of British national identity possible. The Jummapur Cricket Club in Indian Ink, which is associated with the national British/ English identity, with its British way of decorations and architecture, should also be re-considered within this context.

What is more, the fact that the British tried their best to construct a homogenous atmosphere in the majority of the clubs in India which limited the right to enter only to the British and some Europeans tells significant points in relation to race relations and British colonial and imperial politics. 
In Stoppard's Indian Ink, the Jummapur Cricket Club, which is a cricket club as the name implies, too, is observed to have only British members and guests. The representation of this homogeneity might be exemplified with many instances: All the characters in the club in the play are English: Durance, Flora, the Resident, Englishwoman, and Englishman. The following descriptions in the stage direction have evidential value: "The Jummapur Club after sundown. Gramophone music. Three couples are dancing: Flora and Durance, the Resident and the Englishwoman, and a third couple, an Englishman and English Lady" (Stoppard, 1999: 431). Stoppard's emphasis upon the nationality of some of the characters (like Englishman and Englishwoman) rather than upon their names mirrors the significance of this homogenous society structured by means of national identity and discrimination against the indigenous people. As Sinha accentuates, "[t]he clubs, by their very nature as self-selecting institutions, confined their membership only to 'select people': mainly elite European bureaucrats, military officials, and nonofficials (those who were not in the employ of the government)" (2001: 505). By means of a metaphorical structure that emphasises the "difference" of the indigenous from the British and the similarity among themselves, the British, in a way, constructed "means of "production of knowledge and strategies of representation"' (Loomba, 2000: 97). In other words, they created a national discourse for themselves which is understood by analogies with "superiority" and racism, terms taken from racial discourse. With the help of this homogenising effort, British (particularly English) nationality was secured and strengthened, and this nationbuilding process contributed to the imposition of Britain's authority.

As a matter of fact, cricket clubs in India were not the only institutions that denied the entrance to indigenous people and that tried to construct this homogeneity, and monolithic representation. It would also be useful to give the information that, in India, there were some other clubs which were particularly for the British. The Bengal Club, which was "established [...] on the model of the recently formed London Oriental Club" (Sinha, 2001: 499), was one such example. It was established in 1827, was the first club in India, and included only British and male inhabitants ${ }^{1}$ (Cohen, 2009: 172). This

\footnotetext{
${ }^{1}$ This sex-selective characteristic of the clubs was the case in all the other colonial clubs, as well, until the end of the nineteenth-century. By the late nineteenth-century, there were more than 20,000 women who lived in India; and, those women had the right to visit the clubs as guests; however, membership was still not possible for them (URL-5). At the fin de siècle, as a consequence of many women's firm insistence on being allowed into the clubs, women were
} 
race-selective characteristic of the Bengal Club was observed in the majority of the British clubs in India, too, due to the exclusive characteristic of the British society in India.

As a result of this race-selective characteristic of the colonial clubs, the first step of the admission to the club was generally the presence of a friend in the club (James, 1997: 170), and as Captain Williamson explained, "'he who knows nobody, him will nobody know”' (qtd. in James, 1997: 171). So, social ties that provide a familiar identity in the club are a significant factor in the "clubbability". This "clubbability" is exemplified and emphasised in Indian Ink within the dialogue between Durance and Flora:

Durance: Usually we know of arrivals because the first thing they do is drop in a card [...]. Are you an old hand here, Miss Crewe? Flora: No, I've never been to India before. I came up from Bombay just a few days ago.

Durance: But you have friends here, perhaps?

Flora: No. I got on a ship and I came, knowing no-one. I have friends in England who have friends here. Actually, one friend.

Durance: In Jummapur, this friend?

Flora: No - the friend - my friend - is in London, of course; Mr Joshua Chamberlain. His friends are in different places in Rajputana, and I will also be going to Delhi and then up to the Punjab, I hope.

Durance: Now I see. And your friend in London has friends in Jummapur.

Flora: Yes. (Stoppard, 1999: 396).

Besides, British guests who have such social ties and have the right to visit the club are treated in a friendly manner, and called as "honorary" people, which might clearly be observed in an exchange between Durance and Flora in Indian Ink: "[A]musing our distinguished visitors is among my duties. [...] Meanwhile, please consider yourself an honorary member of the Club - mention my name, but l'll put you in the book" (Stoppard, 1999: 397). This "honour" title was given only to a limited number of people who fulfilled the conditions of the institutions where people who met on a common ground in terms of nationality, race and/ or similar ideologies came together. As Steven Patterson states, "[h]onour therefore operated as a unifying concept for Anglo-Indian society - much like the clubs themselves - and

accepted into the clubs only to avail of the facilities, not as "voting members," which led to the establishment of separate women's clubs (Cohen, 2009: 172). 
worked within a social hierarchy so that honour could usually be claimed by those with a British background, bringing most Anglo-Indians into the honour group. The club marked Anglo-Indians as 'clubbable,' acceptable, and culturally "white'" (2009: 32). Flora, as an elite English/ European woman, "deserves" to be an "honorary member" of the Jummapur Cricket Club, which might be observed in her following words: "And everyone at the Club was very friendly" (Stoppard, 1999: 436). This is a clear proof of Eurocentrism/ Western-centrism," and signifies favouritism towards Europeans and Western countries, towards the ones who are not "different," but who share similar psychological, cultural and social atmosphere.

In addition to this representation of the club as a place where the interests, shared experiences and psychologies of the imperial power are present, its existence as a space that stresses the submissive nature and marginalised and "inferior" positions of the "non-European" in the hierarchical system should be emphasised, too. The walls of the club, dominated by " '[t] he sense of being "aliens under one sky,' surrounded by a hostile climate and people" (Patterson, 2009: 184), in this respect, represent the physical and symbolic division of the indigenous and the coloniser that further widened the gulf between these two different communities. In fact, the British had the fear for the existence of "dark, occult places in India beyond their reach" (Patterson, 2009: 42), and they "deem[ed] most Indians as belonging to such shameful locations, where the heavy tread of the European had not yet imposed order, and where it had little hope of doing so" (Patterson, 2009: 42). As a requirement of this imperialistic discourse, which is racist at the same time, the British preferred to stay at places "where one could be physically apart from the chaos, dirt, and noise of India" (Patterson, 2009: 119), from "unreliable" people and illness, which is expressed, throughout Indian Ink, with the conversations between Durance and Flora in the Jummapur Cricket Club in many instances. In one of them, the Indians, even the cultured and educated ones like Nirad Das are represented as "unreliable" people who cannot keep secrets and are easily accused of spreading news (Stoppard, 1999: 445). In such a stereotypical representation of the Indians in which even an educated Indian is subjected to suspicions, the traces of a colonial discursive formation are observed. In another, the Indians are associated with illness, which is understood by the words uttered by Durance: "People here drop like flies - cholera, typhoid, malaria - men, women and children, here one day, and the next" (Stoppard, 1999: 438). Durance, with this stereotypical representation, associ- 
ates the Indians with filth and illnesses, "making 'a metaphoric connection between organic, climactic and moral degradation"' (Lee, 2002: 45).

It is observed that the India constructed in the imaginary world of the imperial power was like an empty space waiting to be filled with and occupied by the imperial discourse in which she is accepted as the absolute anti-thesis of Britain/ Europe. Throughout the British Raj, a vast number of binary oppositions and stereotypes had been constructed, and the following ones stand out among them: "[I]f colonised people are irrational, Europeans are rational; if the former are barbaric, sensual, and lazy, Europe is civilisation itself, with its sexual appetites under control and its dominant ethic that of hard work; if the Orient is static, Europe can be seen as developing and marching ahead; the Orient has to be feminine so that Europe can be masculine" (Loomba, 2000: 47). All these stereotypes and binary oppositions made up throughout the colonisation process for the Indians by the British in India made language a metaphorical weapon directed at the so-called "inferior" people as a means of humiliation of the indigenous and of praise for the British. This situation causes the indigenous people to be entrapped within "the circle of interpretation" (Bhabha, 2002: 83), and which structured a discipline that helped the "production" and manipulation of the "East" by the "West." Humiliating the colonised in line with the racist stereotypical discourse was used by British colonisers in order to make the power-building process in the ladder of the races possible, and guarantee and maintain this power. These discriminatory ideologies were institutionalised by means of the club where British colonisers never hesitated over uttering these words. The club, in this sense, served the administrative, cultural and racial hierarchisation constructed by colonisers. "Thus the Club can be read as the most anglomorphic site in India, the antithesis of the bustling bazaars of India, its walls serving 'as a metaphor for its bounded and limited culture"' (DeLoughrey, qtd. in Crane, 2011: 19). These stereotypes were used as instruments of justification for the Anglo-Indians who wanted to keep away from the Indians and the places likely to be dominated by them like the bazaars, not to have any contact with them, and, as a result, they built specific locations peculiar to themselves such as clubs and bungalows. It is a fact that there were millions of Indians who had not seen an English person during the British Raj (Loomba, 2000: 111) due to the fact that the British built strict lines between the "self" (coloniser) and the "other" (colonised). This actually makes the etymology of the term "club" relevant to the discussion of race issues in the club. As Sinha notes, "[t]he 
etymology of 'club' - which derives from 'cleave,' meaning both to split and to adhere, that is, 'uniting to divide' - nicely captures its ambivalent political function in colonial India" (2001: 503). The "us" and "them" dichotomy is an instrument for the colonisers to build a strong hegemonic world. The marginalisation of the indigenous Indians who were bombarded with encoded representations associated with being the "other" helped the reconstruction of the identity of British colonisers as "the imperial power." It seems that in order to preserve the prestige and name of the British Empire, the British had to cling resolutely to their imperial ideologies. Hence, the club in India became a space in which the British performed their power games in the geographical and political hierarchical ladders of the world, which resulted in the underestimation of what non-Western societies represented and in the denial or peripheralisation of the other civilisations in the remaining parts of the world. In this power game, India, once called by British Prime minister Disraeli as the "jewel in the crown of England," was regarded as a political geography, a symbol of Britain's colonial overseas power, as a performance of the British, and, in a wider sense, Western imperial ideologies in the "East," which "becomes what [again] Disraeli identified as a "career"' (Bhatia, 2009: 225). In this sense, the club is the micropolitical representation of these Western imperial ideologies.

Moreover, already surrounded by such discriminatory and prejudiced thoughts against the Indians, the British used the Indian Uprising ${ }^{2}$ in 1857 as an instrument for the justification of the colonial rule and the establishment of separate buildings in India. As Mark Pafford emphasises, this event "had been taken as proof that the Indians were barbaric people whom it was a heroic duty to rule and civilise" (1989: 2). As a consequence, India took its place in the European maps as a "dangerous, cruel and threatening Oriental" region, and, the British further emphasised the "necessity" of the British

\footnotetext{
${ }^{2}$ For the Indians, the 1857 event called by them as an "uprising" was an effort to reconstruct their socio-political/ cultural identity and heritage and was a freedom struggle against the colonial rule. On the contrary, the British understood this event as a "mutiny," which connotes a rebellion against the British Raj, and a kind of threat to the established order. In Indian Ink, the use of these two terms by Flora (an English woman) and by the Rajah (Indian) is reflected as follows:
}

Rajah: My grandfather stood firm with the British during the First Uprising.

Flora: The...?

Rajah: In 1857 the danger was from fundamentalists -

Flora: The Mutiny... (Stoppard, 1999: 456). 
Raj, which would bring the so-called "British/ European civilisation" to the land which is associated with " "an unchanging text' of a primitive and static Hinduism" (Singh, 1996: 3). This exemplifies how the Indian Uprising triggered the myth-making process of the imperial power, that is to say, the construction of social, political, geographical and philosophical "truths" and discourses about the "Orient," which were empirical and biased. These "truths" aggravated the situation and made the communication with the indigenous people who have a different culture and nationality more difficult, and many British people in India went on establishing new clubs. The number of the clubs increased particularly in the second half of the nineteenth-century as they saw these places as "shelters" for themselves against the "rebellious" and "primitive" natured indigenous people, and as institutions that embodied the "virtues" of British culture and civilisation against the "monstrosity" and "barbarism" of the indigenous Indians. The association of the British with "civilisation" is emphasised by Durance in the club in Indian Ink with the sentence, "We're a reasonably civilised lot" (Stoppard, 1999: 399) (He means the ones in the club). Durance is a character who represents the imperial ideologies and who keeps loyal to the "civilising mission" discourse, and Eurocentric worldview, and who, in each opportunity, voices these ideologies in the club. This "civilising mission" or what Rudyard Kipling (1865-1936) calls as "the White Man's Burden"," as a matter of fact, is nothing more than normative ideologies used by European colonisers, especially British colonisers to rationalise the colonisation in India and to widen the gap between the "East" and the "West."

As a consequence of trails of degradations of the indigenous people on the one hand and the effort to see the British at the highest level on the other hand, the clubs had been exclusively the prerogative of the elite white Europeans, and the Indians were not deemed by the British worthy of being the members of their social clubs. ${ }^{4}$ Such categorisation of the Indians is reflective of the Orientalist discourse "that took a backward and downward direction towards the species category, which was supposed also to be an ontogenetic explanation for every member of the species" (Said, 1979: 231). Edward Said's argument about Orientalism reflects a generalisation made by the Europeans for all the "Eastern" indigenous people. All

\footnotetext{
${ }^{3}$ The title of one of his poems written in 1899 to encourage American imperialism and colonialism in the Philippine Islands in the war between the Philippines and America (1899-1902).

${ }^{4}$ During the British Raj in India, even "No dogs or Indians" signs were used at the outer parts of many British institutions (URL-1).
} 
the indigenous people regardless of their education or cultural level were classified within the category of "them" contrary to "us" because the "Oriental was a member of a subject race, he had to be subjected: it was that simple" (Said, 1979: 207). The homogeneity of the clubs ${ }^{5}$ and the colonial discourse which triggered the sharp binaries between the East and the West did not allow the entrance of even the middle-class, intellectual and "Europeanised," or "Anglicised" Indians who looked like, spoke and behaved like their colonisers, either. In Indian Ink, this discrimination against the educated elite Indians is reflected in the following quotation:

Flora: Is he Army? No - how silly -

Durance: He's Indian Civil Service. The heaven-born. A Brahmin.

[...] We have Indian officers in the Regiment now. My fellow Junior here is Indian, too, terribly nice chap - he's ICS, passed the exam, did his year at Cambridge, learned polo and knives-and-forks, and here he is, a pukkah sahib in the Indian Civil Service.

Flora: Is he here?

Durance: At the Club? No, he can't come into the Club.

Flora: Oh. (Stoppard, 1999: 439-440)

This quotation quite clearly reflects the privileged treatment to the white elite Europeans and the humiliation and racism directed at even the elite Indians, and, the paradoxical situation they are in, which problematises the position of the elite indigenous in the hierarchical ladder, and their representation in the club openly portrays their place in the location of culture as the "Oriental." The Orient is not naturally Orient, but it is merely the ideological, geographical and political construction of Europeans, which is emphasised by Said within the following words: Oriental "is made Oriental" (Said, 1979: 7), and "such locales, regions, geographical sectors as 'Orient' and 'Occident' are man-made" (Said, 1979: 5). Such an inferior representation of the Indians in India is a discursive form of weapon directed at the "Orient" to contribute to the power-building process and "the establishment of imperial claims" (Singh, 1996: 28) since throughout the colonisa-

\footnotetext{
${ }^{5}$ Many attempts to bring together the elite Indians and Europeans failed. Only in the 1920s and 1930s, there was great insistence on the removal of the rules of the club that excluded Indians as members or guests in the European social clubs in India. During the interwar period, in many race-selective clubs that previously had accepted only white Europeans, at least honorary memberships began to be bestowed upon Indian officials, particularly in the country stations (Sinha, 2001: 515).
} 
tion period the Orientalist discourse caused the Indians to be the objects of British imperial ideologies. Any trace of being identified with "them" would mean to accept them as their "equals" and, then, the boundaries between the "East" and the "West" would be challenged. The Jummapur Cricket Club and the problematic position of the Indian soldier, who is not accepted into it in Indian Ink as he is regarded as an (in)visible and objectified "other" who is "nameless," "absent" and "grant[ed] [...] an abstract humanity" (Singh, 1996: 55), mirror colonial racism, peripherisation/ otherisation and typify the East-West dichotomy. In this division according to the constructed identity politics, the honorary class that deserves the "clubbability" is accepted to be the British, and, in a more general classification, the Europeans. Constructing an imaginary "inferior" "other" and binary oppositions, and looking at this "other" from the perspective of the imperial power might be considered as "a narcisstic way" of accepting himself and his colonial identity (Behdad, 2006: 131). In other words, in their constructed discourse, in a way, the colonial authority depends on racial discrimination, on formulating binary oppositions between them and the colonial subject. A formulation like this is observed: "I am not the Other, and the Other is not "l" (Behdad, 2006: 118); "I am the power/ the master, and the Other is the submissive one/ the servant." The club, as the embodiment of this hierarchical structure of the colonialist racial ideology, serves the imperial power, and reflects race issues, the divisions and prejudices of the Empire, and, hence, the politics of space.

The exclusion of even the elite Indians from the club shows that space can't be dissociated from politics and ideology. The imperial power still finds a way, an imaginary "truth, fact" to prevent the entrance of the elite Indian into the club. The "in-between" or even "mimic man" position of the elite soldier outside the Jummapur Cricket Club is a tool for the imperialists to feel superior to the indigenous Indians and a mechanism that helps the establishment of the inferior representation of even the elite indigenous. As Josephine Lee points out, "[a]lthough natives were supposedly reformed by receiving the proper literary education, serving in the military, and playing cricket, they would always remain imperfect copies of the white British" (2002: 47). This problematic issue stems from Thomas Babington Macaulay's famous "Minute on Education" (1835) programme. As a requirement of this programme and the imperial ideologies, English education in India became compulsory, which is also a trace of cultural imperialism in the country, and which is voiced by Nirad Das in the play with these words: "I 
have to thank Lord Macaulay for English, you know. It was his idea when he was in the government of India that English should be taught to us all. He wanted to supply the East India Company with clerks, but he was sowing dragon's teeth. Instead of babus he produced lawyers, journalists, civil servants, he produced Gandhi!" (Stoppard, 1999: 393). The Macaulay education project, which is a perfect representation of what Louis Althusser calls "ideological state apparatus," particularly, a cultural, educational and political ideological state apparatus, was also a tool for colonisers to deliberately estrange the indigenous people from their customary, historical and cultural past, and a tool to succeed in colonisation. About the function of the Macaulay Education programme, Macaulay stated as follows: "We must at present do our best to form a class who may be interpreters between us and the millions whom we govern, --a class of persons Indian in blood and colour, but English in tastes, in opinions, in morals and in intellect" (URL-2). This education system was Euro-centric, even ethno-centric (English-centric), and it helped the British to shape and reshape the history of the British Empire, the colonies including India, the colonial subjects according to their own perspectives and ideologies. In this history-writing process, the colonised did not have any right to voice themselves, their needs or desires. The Macaulay Education programme seems to have served British interests and to have made it easier for the British to "inevitably promote Indian loyalty to British rule" (Cutts, 1953: 825), to form British culture in the minds of the colonised as "superior" and to perpetuate the colonial rule. The imposition of the English culture upon the Indians and its negative impact upon the traditions and cultures of the colonised are mirrored by Nirad Das' son, Anish as follows: "Even when you discovered India in the age of Shakespeare, we already had our Shakespeares. And our science - architecture - our literature and art, we had a culture older and more splendid, we were rich!" (Stoppard, 1999: 390), and it is reflected by Nirad Das in the following way: "The bloody Empire finished off Indian painting!" (Stoppard, 1999: 427). These two examples show that before British colonisation, the Indians had already had their own culture and history, and the British did not have historical and cultural precedence and superiority over the Indians, and all cultural, artistic and traditional Indian ways of life had been buried throughout the colonisation period by means of the Indians' being exposed to English education and culture. This education made possible the internalisation and acceptance of British culture, language and literature, and even "convince[ed] the natives that colonialism was natural, in- 
evitable, and even progressive" (Blaut, 1993: 25), and fastened the "colonisation of the mind." This is exemplified in Indian Ink by the abovementioned Indian soldier who is the elite of the ICS (Stoppard, 1999: 439), which stands for the Indian Civil Service/ the Imperial Civil Service. The soldier has been educated like an elite English man is educated, and is a perfect representation of Macaluay Education programme with his "Indian blood" and "English tastes." The elite Indian soldier's experience of being excluded from the club shows that he has accepted his "secondary" and "inferior" position, and he has left the claim of his identity and culture to his so-called "protector." His position and the conditions he is in also prove that even "Anglicised" elite Indians are never accepted as "equals," because in colonial mimicry, "to be Anglicised is empathically not to be English" (Bhabha, 2002: 87). This idea was used by the British as an intermediary instrument between themselves and the common indigenous people in India; and, it was associated with colonial mimicry, which is "the desire for a reformed, recognizable Other, as a subject of a difference that is almost the same, but not quite" (Bhabha, 2002: 122), "almost the same, but not white" (Bhabha, 2002: 128). Their education level, their appearance and behaviours like the English, the metaphorical British mask they wear were not enough for British colonisers in India to accept them as equivalent to themselves. Even the British education model which brought so-called "civilisation" to them was away from "elevating" them to the level of the British; hence, to Bhabha's descriptions of the elite colonial subject, another description might be added: "almost 'equal' but not quite." As John McLeod puts forth, "[h]earing their language coming through the mouths of the colonised, the colonisers are faced with the worrying threat of resemblance between coloniser and the colonised. This threatens to collapse the Orientalist structure of knowledge in which such oppositional distances are made" (McLeod, 2012: 66). Hence, the "differences" rather than "similarities" are tried to be emphasised by British colonisers. Actually, to accept the elite Indians into the club would mean to shatter the Orientalist discourse where "East and West are positioned through the construction of an unequal dichotomy" (McLeod, 2012: 49). These treatments reflect the pseudo-objectivity and pseudo-humanity of colonisers as they granted the special privileges to their own race, which proves the close link between colonial racism and esprit de corps that British colonisers developed in the colonised lands. Hence, the race-selective characteristic of the club should also be considered in parallel with its function of reinforcing the British im- 
perial identity since it helped the circulation of the knowledge of the imperial discourse.

Before concluding the paper, it would be relevant and pertinent to briefly talk about the representation of Rudyard Kipling in the Jumapur Cricket Club in Indian Ink in relation to the imperial context of the play and to the "White Man's Burden" myth. As a matter of fact, Kipling is both a national and an imperial symbol of Britain, and, "[f]or many, Kipling served as the embodiment of the Anglo-Indian as ideal coloniser and as racial saviour" (Hart, 2012: 2). The mention of Rudyard Kipling in the part where an Englishman is reciting some lines from his "Mandalay" (1890) should be discussed in relation to the interests of the imperial ideologies. As already mentioned previously in this article, poetry reading was one of the cultural and national activities in the club. Kipling's imperial and national identity which is foregrounded with the content of the poem contributes to the construction of a bridge between imperialism and nationalism. Only the following lines of the poem are presented by Stoppard in Indian Ink:

The Kipling fan, unseen, is singing:

Englishman:

'On the road to Mandalay

Where the flyin' fishes play,

An' the dawn come up like thunder outer China

Crost the Bay!'

The dancers disperse. (Stoppard, 1999: 433).

The choice of use of "Mandalay" by Stoppard in Indian Ink is significant here, because when the whole poem is read, it is observed that the poem's central focus is upon the politics of race and imperialism. It is about a British soldier who has turned back to London from Burma, and it is understood that he is in a deep colonial nostalgia, who yearns for his days in Burma, which was part of India until 1937. With his imperialistic desires, the persona in the poem might be regarded as Kipling's voice. As a matter of fact, "Kipling's view of imperialism as a national duty and as a fundamental aspect of national identity becomes entrenched in the national psyche" (Hart, 2012: 3). The recitation of a Kipling poem in the club by an Englishman who is a Kipling fan offers ample attestation of the association between the proimperialist policy/ attitude of the members of the Jummapur Cricket Club and nationalism. The "Kipling-haunted little Clubs" (Orwell, 1934: 69), and, in Indian Ink, the Jummapur Cricket Club, in this sense, at a micro level 
might be a symbol of the British Empire through which they would certainly enhance the value of their empire and nationalistic ideologies.

\section{Conclusion}

In line with all the discussions in this article, it might be concluded that British clubs in India, as also exemplified by Tom Stoppard's Indian Ink, are reflective of British imperial ideologies and national identity. Hence, these architectural constructions, as "a potent signifier of Empire" (Crane, 2011: 19), are more like symbolic representations of imperial otherising methods and constructed racism in India than just buildings made of stone. In this regard, with their dividing and discriminative characteristics within the racial context, those clubs are cultural, political and national symbols/ emblems of colonial expansion in the colonial spheres, East-West dichotomy and the Eurocentric worldview that otherise all the other geographical spheres as the periphery, the discriminatory process in all spheres of life throughout the British Raj. In such a sphere, the colonial club might be regarded as encapsulating in miniature the characteristics of colonial India as a whole.

\section{References}

Behdad, Ali (2006). Kolonyal Çözülme Çağında Oryantalizm. Trans. Sibel Erduman and Berkay Ersöz. İstanbul: Chiviyazıları.

Bhabha, Homi K. (2002). The Location of Culture. New York: Routledge.

Bhatia, Nandi (2009). "Reinventing India through 'A Quite Witty Pastiche': Reading Tom Stoppard's Indian Ink”. Modern Drama, 52(2): 220-237.

Blaut, J. Morris (1993). The Colonizer's Model of the World: Geographical Diffusionism and Eurocentric History. New York and London: The Guilford $P$.

Boehmer, Elleke (1995). Colonial and Postcolonial Literature: Migrant Metaphors. Oxford: Oxford UP.

Cohen, Benjamin B. (2009). "Networks of Sociability: Women's Clubs in Colonial and Postcolonial India". Frontiers: A Journal of Women Studies, 30(3): 169-195.

Crane, Ralph (2011). "Reading the Club as Colonial Island in E. M. Forster's A Passage to India and George Orwell's Burmese Days". Island Studies Journal, 6(1): 17-28. 
Cutts, Elmer H. (1953). "The Background of Macaulay's Minute”. The American Historical Review, 58(4): 824-853.

Dickens, Charles (Jr) (1882). Dickens's Dictionary of London. London: Macmillan \& Co.

Hart, Catherine Elizabeth (2012). English or Anglo-Indian?: Kipling and the Shift in the Representation of the Coloniser in the Discourse of the British Raj. Doctoral Dissertation. Ohio: The Ohio State University.

James, Lawrence (1997). Raj: The Making and Unmaking of British India. London: Little, Brown and Company.

Lee, Josephine (2002). "In the Native State and Indian Ink". Ed. Katherine E. Kelly. The Cambridge Companion to Tom Stoppard. Cambridge: Cambridge UP, 38-52.

Loomba, Ania (2000). Colonialism/ Postcolonialism. London and New York: Routledge.

McLeod, John (2012). Beginning Postcolonialism. Manchester and New York: Manchester UP.

Orwell, George (1934). Burmese Days. London: Penguin.

Pafford, Mark (1989). Kipling's Indian Fiction. New York: Palgrave Macmillan.

Patterson, Steven (2009). The Cult of Imperial Honour in British India. New York: Palgrave Macmillan.

Prakash, Gyan (1994). "After Colonialism”. Ed. Gyan Prakash. After colonialism: Imperial Histories and Postcolonial Displacements. Princeton: Princeton UP, 3-17.

Russell, Richard Rankin (2004). “'It will Make Us Friends': Cultural Reconciliation in Tom Stoppard's Indian Ink". Journal of Modern Literature, 27(3): 1-18.

Said, Edward (1979). Orientalism. New York: Vintage Books.

Singh, Jyotsna G. (1996). Colonial Narratives/Cultural Dialogues: "Discoveries" of India in the Language of Colonialism. London and New York: Routledge.

Sinha, Mrinalini (2001). Britishness, Clubbability, and the Colonial Public Sphere: The Genealogy of an Imperial Institution in Colonial India. Journal of British Studies, 40 (4): 489-521.

Smith, Anthony D. (1991). National Identity. New York: Penguin. 
Stoppard, Tom (1999). Plays five: Arcadia, The Real Thing, Night and Day, Indian Ink, Hapgood. Kent: Faber and Faber.

Timbs, John (1867). Curiosities of London. London: J. S. Virtue and Co. Ltd.

URL-1: Dhillon, Amrit (2017). “'No dogs or Indians': Colonial Britain Still Rules at India's Private Clubs". The Sydney Morning Herald. https://www.smh.com.au/world/no-dogs-or-ndans-colonal-brtanstll-rules-at-ndas-prvate-clubs-20170630-gx1vtk.html (Access: 05. 08.2020).

URL-2: Macaulay, Thomas Babington (1835). "Minute by the Hon'ble T. B. Macaulay".http://www.columbia.edu/itc/mealac/pritchett/00generallinks/macaulay/txt_minute_education_1835.html (Access: 15.08. 2019).

URL-3: Milne-Smith, Amy (2013). "Imperial Club Life in London". http://www.victorianweb.org/history/leisure/imperial.html (Access: 21.08. 2019).

URL-4: "Oriental Club". (n.d). https://www.orientalclub.org.uk/ (Access: 12.02.2021).

URL-5: Srinivasa-Raghavan, TCA. (2015). "Club Culture ... A British Legacy”. Rotary News. https://rotarynewsonline.org/club-culture/ (Access: 21.01.2021).

The following statements are made in the framework of "COPE-Code of Conduct and Best Practices Guidelines for Journal Editors":

Authors' Note: This article is the revised and expanded version of my paper presented at El Ruha $5^{\text {th }}$ International Conference on Social Sciences (2019) in Tunisia with the title, "Colonial British Clubs in India as the Symbol of Racism: Tom Stoppard's Indian Ink."

Ethics Committee Approval: Ethics committee approval is not required for this study.

Declaration of Conflicting Interests: The author has no potential conflict of interest regarding research, authorship or publication of this article. 